\title{
Foreword
}

\section{Charles Goodhart}

At a time when both the organisation and processes of financial regulation and supervision are in a state of flux, it is good and topical to have a book reporting on the state of play on these matters in Europe. Moreover the editor, Donato Masciandaro, is to be congratulated on having assembled, as authors for the contributing papers, the leading European experts in the field. They write with knowledge, insight and authority.

The book is divided into three main parts. The first three chapters (Herrero and del Rio; Oosterloo and de Haan; Masciandaro) are primarily about the interactions between the continuing Central Bank oversight of Financial Stability and the on-going shift of responsibility for banking supervision to a unified Financial Services Authority. The reasons for this latter shift are clear enough, e.g. the blurring of sectoral divisions between banking, insurance and securities' business, concerns about the powers and reputation of (operationally) independent Central Banks. At the same time, however, Central Banks, with their Lender of Last Resort powers and concerns about the smooth working of payments systems in the economy, neither could, nor would want to, slough off their more general responsibilities for financial stability. But what does this latter amount to in practice, when responsibility for supervising all individual financial institutions, including all banks, passes to an FSA? What is to be the modus vivendi between Central Bank, FSA, and Ministry of Finance?

The three chapters in Part I deal with this issue analytically and in general. Unusually in this field, Masciandaro has also undertaken some empirical/econometric work on this subject. The eleven chapters in Part II and the last chapter deal with this same issue practically and with respect to ten separate European countries. 
The authors are mostly members of their own FSAs, and can speak to their subject, i.e. The Emerging Role of Single Financial Authorities, with direct, inside knowledge. They comprise:

Chapter 5: UK (Sykes and Allen; Financial Services Authority).

Chapter 6: Austria (Grünbichler, Financial Market Authority).

Chapter 7: Denmark (Bjerre-Nielsen, Financial Services

\section{Authority).}

Chapter 8: Sweden (Bonde, Financial Supervisory Authority).

Chapter 9: Norway (Aamo, Financial Services Authority).

Chapter 10: Estonia (Liive, Ministry of Finance).

Chapter 11: Hungary (Balogh, Financial Supervisory Authority).

Chapter 12: Germany (Schüler, ZEW).

Chapter 13: The Netherlands (Prast and Van Lelyveld, De Nederlandsche Bank).

Chapter 14: Ireland (Westrup, Boston University).

These primarily factual chapters will be of great reference value, and will teach many new details to most readers, especially with respect to countries other than their own.

The link between these reports of individual national supervisory frameworks and the wider European dimension is made in the first chapter of Part III by Moss, the international co-ordinator at the Kredittilsynet in Norway, who reports not only on the complicated structure of European co-operative and co-ordinating regulatory bodies and procedures, but also how the interface between national and European regulatory activities is taking up an increasing amount of regulators' time and effort. Learning, and remembering, the growing (and ever changing) list of acronyms for all these bodies is becoming an ever harder task, often leaving neophytes with no understanding of what the cognoscenti are talking about!

This final part then comprises another three papers (by Schoenmaker, Eijffinger, and Lannoo). The main theme is the relationship between regulation/supervision at the European/federal level and at the individual nation state level; (the yet wider global interaction with BIS, the Basel Committee on Banking Supervision, IMF, etc., does not figure much here). One interesting feature is that the trend towards the unification of supervision at the national level is not replicated at the European level, where separate bodies for discussion of common regulatory/supervisory issues have been 
established for banking, insurance and securities business. Of greater concern to these authors is the question of where financial regulation in Europe should be headed, towards greater centralisation at the federal level, or kept decentralised at the national level. Schoenmaker and Eijffinger hanker after more centralisation, but Lannoo injects some welcome political realism. Such centralisation is not about to happen, because national Ministries of Finance, who will pick up the bill for any financial rescues, do not want it to happen.

Dirk Schoenmaker reports a 'trilemma' in this field whereby you can have any two, out of three objectives, (1) integrated financial market, (2) national financial supervision, (3) a stable financial system. In effect we now have (2) and (3). The Financial Services Action Programme aims to establish (1). Schoenmaker's concern is that a combination of political support for (2) and an inability to deal with cross-border issues in financial crises will give us (1) and (2), but not (3). So his expectation is that we may be headed for a crisis, and indeed that the occurrence of such a crisis will actually be necessary to make people realise the incompatibility of national financial supervision with integrated financial markets and stability. A frequently heard prayer is that when we run into such a crisis, may it be a small one. We shall see. 